\title{
PENINGKATAN KREATIVITAS KELOMPOK PKK DUSUN KABUN BARU KEC. LUBUK ALUNG MELALUI PELATIHAN SULAMAN
}

\author{
Yulimarni1), Nofi Rahmanita ${ }^{2)}$ \\ 1), 2)Program Studi Seni Kriya FSRD ISI Padangpanjang \\ Jln. Bahder Johan Kel. Guguk Malintang Kec. Padangapanjang Timur Kota Padangpanjang, \\ Sumatera Barat, 27118 \\ E-mail:yulimarni@isi-padangpanjang.ac.id ${ }^{11}$,nofi.tekstil@gmail.com²)
}

\begin{abstract}
ABSTRAK
Pelatihan sulaman diberikan kepada kelompok PKK dusun Kabun Baru Balah Hilir Kecamatan Lubuk Alung. Pelatihan bertujuan untuk mengembangkan danmeningkatkan kreativitas kelompok PKK di bidang ketrampilan danmengenalkan lebih dalam tentang sulaman, sebagai bentuk pelestarian kerajinan tradisional. Permasalahan yang dihadapi kelompok PKK adalah minimnya pengetahuan kelompok PKK di bidang ketrampilan, mengakibatkan program PKK di bidang ketrampilan khususnya di bidang kerajinan kurang berjalan. Dan umumnya kelompok PKK belum pernah mendapatkan pelatihan ketrampilan khususnya tentang sulaman.

Untuk memecahkan permasalahan tersebut, maka pengabdian dilakukan melalui metode ceramah, demontrasi dan pelatihan/ praktek. Berdasarkan dari rangkaian kegiatan pengabdian yang telah dilakukan peserta telah mampu membuat sulaman dan mengaplikasikan teknik sulam pada berbagai media, dan dengan pengetahuan dan kreatifitas yang dimiliki kelompok PKK mampu mengembangkan ilmu kertampilan yang diperoleh kepada ibu-ibu dan remaja putri yang ada di sekitar dusun Kabun Baru dan kecamatan Lubuk Alung secara luas, sehingga diharapkan nantinya dapat melahirkan industri-industri rumah tangga dengan demikian tujuan PKK untuk mensejahterakan keluarga dapat dicapai.
\end{abstract}

Kata kunci: kreativitas, sulaman, produk

\section{PENDAHULUAN}

PKK merupakan gerakan yang tumbuh dari bawah oleh perempuan sebagai penggerak dalam membangun, membina dan membentuk keluarga guna mewujudkan kesejahteraan keluarga. Lebih jauh dalam rapat kerja nasional (rakernas) PKK tahun 2015 dibunyikan bahwa PKK adalah Gerakan Nasional dalam pembangunan masyarakat yang tumbuh dari bawah, pengelolaannya dari, oleh dan untuk masyarakat.Gerakan PKK bertujuan memberdayakan keluarga untuk meningkatkan kesejahteraan menuju terwujudnya keluarga yang beriman dan bertaqwa kepada Tuhan Yang Maha Esa, berakhlak mulia dan berbudi luhur, sehat sejahtera lahir dan batin. Berdasarkan hal tersebut jelas bahwa sasaran dari gerakan PKK adalah keluarga, bertujuan untuk meningkatkan dan mengembangkan kemampuan dan kepribadian anggota keluarga baik di bidang mental spiritual, maupun fisik materialnya.

Tantangan dan persaingan di zaman era globalisasisangatlah ketat, untuk menghadapi hal itu sangat dibutuhkan peran aktif dari segenap lapisan masyarakat untuk menumbuhkembangkan pembangunan yang merata, berkualitas, sikap dan prilaku yang mandiri, agar tidak keliru dalam menerima globalisasi. Untuk menjalankan tanggung jawab yang dibebankan kepada kelompok PKK, maka disusunlah 10 program pokok PKK yang pada hakekatnya merupakan kebutuhan dasar setiap manusia. Salah satu kebutuhan dasar itu adalah meningkatkan dan mengembangkan kemampuan dan kepribadian di bidang fisik material melalui peningkatan pendidikan, pengetahuan dan ketrampilan.

Setiap kelompok PKK di berbagai wilayah Indonesia berupaya memberikan hal yang terbaik kepada masyarakat dengan menciptakanberbagai kegiatan positif, seperti memberikan pembekalan berbagai ketrampilan kepada masyarakat, agar bisa mengembangkan potensi yang dimiliki, kreatif dan mandiri, dengan harapan masyarakat dapat meningkatkan kesejahteraan 
keluarga danmenciptakan lapangan kerja.Kenyataandilapangan hal tersebut belumlah berjalan sesuai dengan harapan, seperti halnya masyarakat yang ada di dusun Kabun Baru Balah Hilir kecamatan Lubuk Alung kabupaten Padangpariaman.

Dusun Kabun Baru adalah salah satu wilayah terkecil yang ada di desa Balah Hilir kecamatan Lubuk Alung kabupaten Padangpariaman. Secara geografis dusun Kabun Baru terletak sangat strategis yaitu di salah satu jalan alternatif menuju Bandara Internasional Minangkabau (BIM), dan jalan menuju tempat wisata seperti pantai Katapiang dan pantai Tiram. Berdasarkan kondisi lapangan, hal tersebut sangat berpeluang untuk mengembangkan usaha rumah tangga seperti diantaranya membuat dan menjual berbagai jenis produk cenderamata dari kerajinan tangan, untuk menunjang wisata yang saat ini sedang digalakan oleh pemerintahan kabupaten Padangpariaman. Oleh sebab itusangat dituntut kreativitas kelompok PKK dusun Kabun Baru di dalam mengembangkan pengetahuannya agar dapat membina masyarakat dan program PKK berjalan tepat sasaran.Untuk itukelompok PKKperlu diberi pelatihan-pelatihan tentangketrampilan khususnya kerajinan tangan dan juga memberikan motivasiagar semangat dan kreativitas mereka menjadi meningkat.

Permasalahan yang dihadapi kelompok PKK adalah kurangnya pengetahuan kelompok PKK di bidang ketrampilan, mengakibatkan kurangnya minat anggota untuk menjalankan program PKK khususnya di bidang ketrampilan. Dan umumnya kelompok PKK belum pernah mendapatkan pelatihan ketrampilan khususnya tentang sulaman.

Berdasarkan uraian latar belakang dan permasalahan, makatujuandari pelaksanaan kegiatan pengabdian ini adalah,untuk meningkatkan kreativitas kelompok PKK dusun Kabun Baru melalui pelatihan sulaman, sehingga merekamampu berkreasi dengan pengetahuan yang dimiliki serta dapat membuat dan menghasilkan produk sulaman, mampu mengaplikasikan teknik tersebut pada berbagai benda kriya. Karena pada prinsipnya sulaman adalah sebuah teknik yang dapat menambah keindahan sebuah benda, sehingga akan meningkatkan nilai jual dari benda tersebut.

Manfaatdari pelatihan yang diberikan adalahtermotivasinya kelompok PKK untukaktif dan dapat mengajak dan mengembangkan potensi yang miliki, tidak hanya dalam kelompok mereka saja tetapi juga kepada masyarakat Kabun Baru dan masyarakat Lubuk Alung pada umumnya, sehingga program PKK dapat terlaksana dan kesejahteraan keluarga dapat dicapai. Selain itu sulaman dapat dikembangkan dan menjadi aset daerah yang dapat menambah pendapatan masyarakat, meningkatkan kualitas hidup, dan menciptakan lapangan kerja.

Kegiatan pelatihan yang bertujuan untuk mendukung program PKK guna meningkatkan pengetahuan dan apresiasi ibu PKK di bidang ketrampilan sebelumnya juga pernah dilakukan di Nagari Sungai Abang Kecamatan Lubuk Alung. Pengabdian dengan judul "Kain Perca sebagai Media Kreasi Ibu PKK Nagari Sungai Abang" dilaksanakan pada tahun 2017. Permasalahan yang dihadapi kelompok PKK di Kecamatan Lubuk Alung semuanya hampir sama, oleh sebab itu denganpelatihan yang diberikan melalui berbagai metode ibu PKK dapat membuat dan menghasilkan produk kriya yang kreatif dan inovatif dengan memanfaatkan limbah kain perca, yang memiliki nilai jual dan dapat meningkatkan pendapatan masyarakat dan kesejahteraan keluarga dapat tercapai. Hasil dari kegiatan ini adalah bertambahnya pengetahuan ibu PKK tentang manfaat kain perca dan trampil dalam mengolah kain perca sehingga peserta dapat membuat dan menghasilkan produk berupa tas mukena, taplak meja, sarung bantal kursidan lain sebagainya. Adapun bentuk produk yang dihasilkan dalam pengabdian kali ini adalah peserta telah dapat mengaplikasikan teknik sulam pada berbagai media seperti sulaman pada kain jilbab, sendal dan dompet anyaman pandan.

\section{METODE PELAKSANAAN PENGABDIAN}

Untuk menyelesaikan permasalahan yang dihadapi kelompok PKK dusun Kabun Baru, di perlukan beberapa metode pelaksanaan. Pelatihan diberikanmelalui metode ceramah;memberikan arahan berupa motivasi tentang pentingnya penguasaan ketrampilan khususnya bagi kaum perempuan baik secara individual maupun berkelompok, menguasai ilmu ketrampilan dapat membuka peluang usaha dan meningkatkan pendapatan rumah tangga, selain itu memberikan penjelasan tentang materi pengabdian terkait dengan dasar-dasar sulam dan aplikasinya pada berbagai media,menjelaskan tahapan-tahapan dalam menyulam mulai dari tahap persiapan sampai pada tahap perwujudan dan pemasaran. Metodedemonstrasi mendemonstrasikan atau 
memperagakan secara langsung cara menyulam, mulai dari mendesain motif, memindahkan motif, penggunaan dan pemasangan alat, cara pengambilan benang yang benar, dan proses menyulam dengan berbagai jenis dan teknik sulam. Metode pelatihan/ praktek; setelah melihat dan memahami proses selama demonstrasi, peserta kemudian mempraktekan teknik sulam sesuai dengan langkah-langkah yang telah diperagakan. Selama praktek berlangsung peserta mendapat pendampingan dari tim, mulai dari awal sampai akhir sehingga peserta pelatihan benar-benar menguasai keterampilan menyulam tersebut dengan baik.

\section{HASIL DAN PEMBAHASAN}

Melalui pendekatan dan koordinasi dengan pengurus PKK dusun Kabun Baru pelaksanaan kegiatan pengabdian dapat berjalan dengan lancar. Melalui kegiatan pengabdianyang dilakukan terkait dengan sulaman terungkap bahwa pada dasarnya masyarakat khususnya kelompok PKK memiliki semangat dan kemauan yang tinggi di dalam melaksanakan perannya sebagai anggota PKK, namun karena keterbatasan ilmu pengetahuan yang dimiliki khususnya di bidang ketrampilan dan kurang bisa membaca peluang mengakibatkan program tersebut kurang berjalan.Sehingga pada saat pelatihan mereka sangat antusias dalam mengikuti pelatihan dan selalu aktif dalam setiap pertemuan.

Berbicara tentang sulaman sebenarnya tidak asing lagi bagi masyarakat sekitarnya, semasa di bangku sekolahpun mereka sudah mengenal sulaman. Sulaman termasuk pada kerajinan yang memerlukan ketelitian dan keahlian tangan, serta sangat praktis untuk diajarkan keberbagai tingkat usia.Di Sumatera Barat sulaman terdapat dan menyebar di berbagai daerah dengan nama dan ciri khasnya masing-masing, seperti diantaranya sulaman benang emas di Nareh, sulaman bayang di Bayang Pesisir Selatan, sulaman kapalo peniti dan suji caia di Koto Gadang, dan dibeberapa daerah lainnya yang ada di Sumatera Barat.Sulaman adalah teknik menghias kain yang dikerjakan dengan tangan maupun dengan mesin dan umumnya dikerjakan oleh kaum perempuan. Sativa menjelaskan bahwa sulaman adalah ragam hias cantuman yang berbentuk jalinan benang di atas kain, sedangkan menyulam adalah "kepiawaian yang digambarkan, dirasa, dan dialami, (1999:18). Sulaman merupakan kerajinan tradisional yang sudah ada sejak zaman nenek moyang. Sebagai kerajinan tradisional hal ini perlu dilestarikan dan dikembangkan di tengah-tengah kehidupan masyarakat.

Hasil kegiatan yang telah berhasil dilakukan adalah peserta menjadi lebih mengerti dan paham peran dan fungsi dari sulaman, bahwa sulam adalah sebuah teknik yang digunakan untuk menghiasi suatu benda agar benda tersebut menjadi lebih indah, sehingga dapat memberikan nilai tambah dan meningkatkan nilai jual. Sulam tidak hanya sebatas menghiasi kain tetapi juga dapat menghiasi benda-benda kriya lainnya seperti tas, dompet, sendal, sepatu dan lain sebagainya. Selain itu peserta juga mengenal lebih jauh macam-macam jenis sulam lebih dari yang mereka ketahui sebelumnya, seperti sulam benang, sulam pita, sulam payet dan di dalam prakteknya selama pelatihan peserta juga sudah dapat mengkombinasikan jenis sulam tersebut pada satu media.

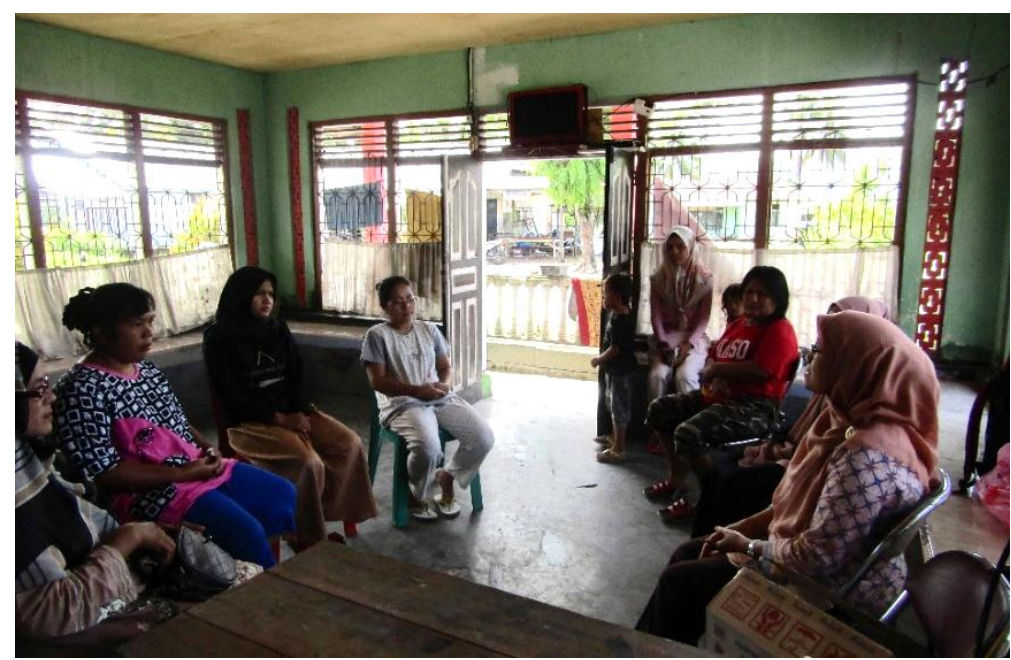

Gambar 1. Mensosialisasikan Program Kegiatan 
Kegiatan pengabdian dilakukan secara bertahap dan sistematik agar peserta mudah memahami setiap tahapan pelatihan. Materi pelatihan diawali dengan perkenalanmedia, bahan, alat, berbagai jenis tusuk sulam dan tahapan-tahapan yang perlu diperhatikan dalam menyulam agar mendapatkan hasil yang baik.Bentuk bahan yang digunakan dalam pelatihan dapat dikelompokan: 1) bahan untuk pembuatan desain motif: kertas HVS, kertas roti, karbon, pensil, penghapus, penggaris. 2) bahan untuk menyulam: benang sulam, pita, dan payet. Sulaman terbentuk dengan menggunakan alat berupa jarum, gunting dan ram atau pemedangan.Penggunaan bahan disesuaikan dengan jenis sulam yang akan dibuat seperti diantaranya, sulaman benang menggunakan benang sebagai bahan utama, sulampita menggunakan bahan pita, sulam payet menggunakan bahan payet, dan sulam kombinasimenggunakan berbagai jenis bahan dalam satu media seperti benang, pita, payet dan lain sebagainya.

Pada tahap demonstrasi dan pelatihan/ praktekada beberapa peragaan yang dilakukan, pertama memperagakan bagaimana pemasangan ram/ pemedangan pada kain, tetapi jika yang disulam itu benda yang sudah jadi seperti tas, sepatu dan lain-lain itu tidak memerlukan ram/ pamedangan. Kedua memperagakan cara pengambilan benang sulam dari pintalannya karena jika pengambilan benang tidak dilakukan dengan baik dan benar maka benang sangat mudah kusutnya.Kemudian dilanjutkan dengan proses pembuatan motif pada media dan proses menyulam.

Di dalam menyulam motif sangat berperan sekali, karena motif di dalam hiasan (ornament) merupakan bentuk dasar atau elemen pokok dalam pembuatan hiasan / ornament. Di dalam KBBI definisi motif adalah pola atau corak hiasan. Oleh sebab itu hal ini sangat perlu diberi pemahaman kepada peserta pelatihan betapa pentingnya peran motif dalam ketrampilan menyulam. Pembuatan motif sulam dapat dilakukan dengan dua acara, pertama pembuatan motif langsung pada media sulam, kedua pembuatan motif pada kertas terlebih dahulu sesuai dengan pola bidang kemana motif akan diterapkan kemudian baru dipindahkan ke media.

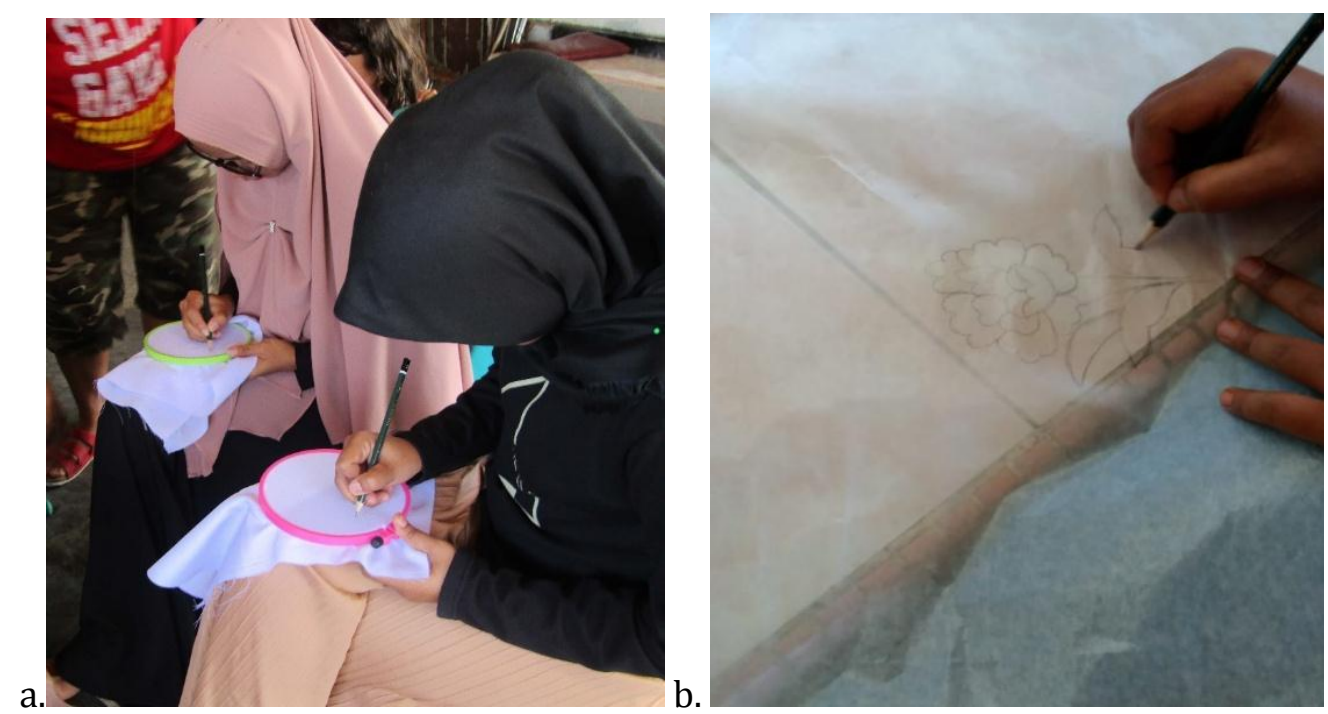

Gambar 2. Peserta sedang melakukan proses pembuatan motif sulam

Sebelum peserta menyulam di media sebenarnya seperti jilbab dan sendal terlebih dahulu peserta latihan menyulam di kain berukuran $50 \mathrm{~cm}$ x $50 \mathrm{~cm}$. Di sini peserta dikenalkan cara membuat berbagai jenis tusuk sulam seperti, tusuk batang digunakan untuk membuat batang, tusuk daun untuk membuat daun, tusuk bullion, suji caia dan tusuk simpul perancis digunakan untuk membuat bunga. Setelah dikenalkan berbagai jenis tusukan kepada peserta, dilakukan evaluasi terhadap hasil yang dibuat, dan diperoleh kesimpulan bahwa peserta sudah dapat melanjutkan ketahap berikutnya yaitumenyulam pada bahan jilbab. Pada tahap ini peserta terlebih dahulu membuat motif pada kertas HVS atau kertas roti dan kemudian baru di pindahkan pada media, selanjutnya pemasangan ram dan menyulam. Dengan teknik yang sama mereka juga dikenalkan dengan jenis sulaman lain seperti sulaman bayang, sulaman benang emas, payet dan pita. Pengaplikasian jenis sulaman tersebut dilakukan pada sendal berbahan korduroi dan dompet dari anyaman pandan.Pada media tersebut desain motif dibuat langsung pada media dan kemudian 
dilanjutkan dengan menyulam. Dilakukannya pelatihan dengan mengenalkan beragam jenis sulaman dan media, bertujuan untuk memperkaya pengetahuan peserta dan untuk meminimalisir kejenuhan peserta.

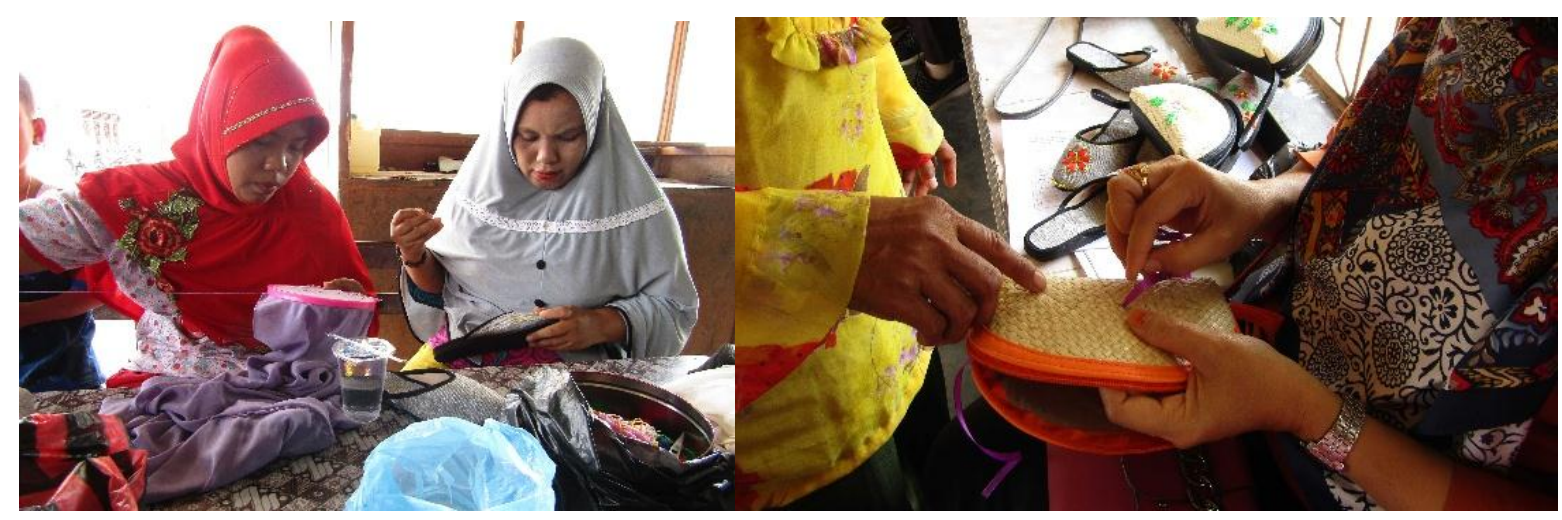

Gambar 3. Peserta melakukan proses menyulam pada berbagai media

Pada umumnya peserta mengikuti kegiatan menyulam dengan antusias, karena selama ini mereka hanya membeli dan memakai produk sulaman hasil tangan orang lain. Sekarang mereka dapat merasakan sendiricara membuatnya, mulai dari pemilihan bahan, membuat motif, memindahkan motih sampai pada proses menyulamnyadan sekaligus dapat menikmati hasil tangan sendiri. Kepuasan mereka yang dapat dilihat adalah ketika merekamencoba mengaplikasikan ilmu yang mereka peroleh ke benda-benda pribadi mereka seperti jilbab, baju dan mukena mereka yang sebelumnya polos kemudian mereka beri sentuhan sulam, sehingga bertambah menarik.

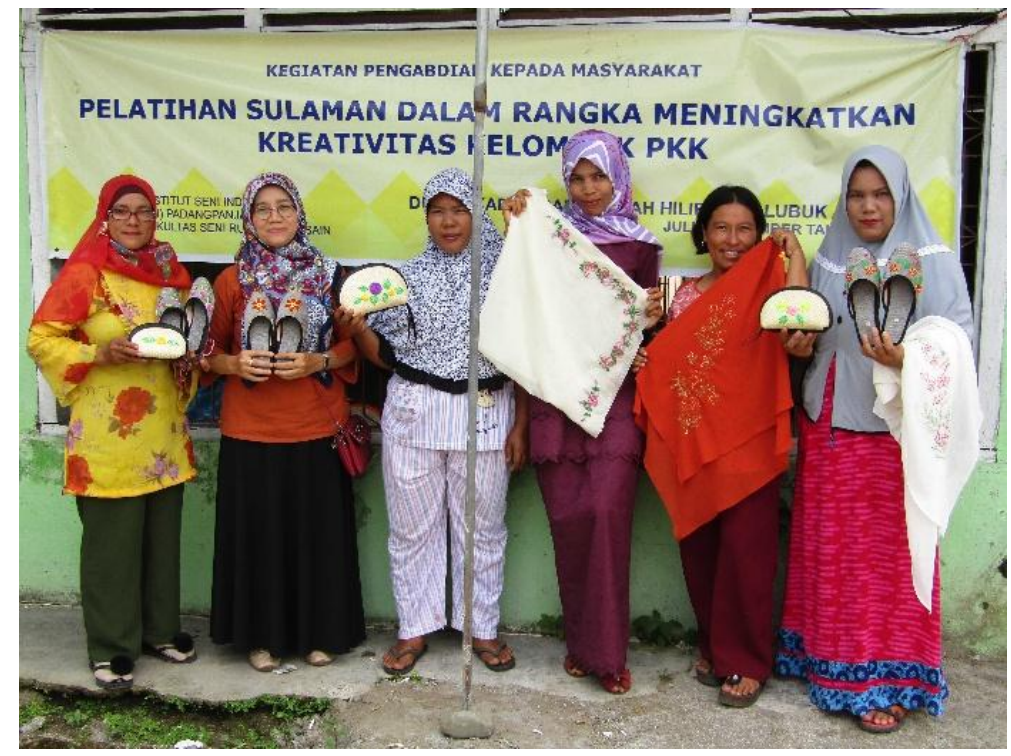

Gambar 4. Hasil sulaman dengan berbagai produk

\section{KESIMPULAN}

Kegiatan pengabdian yang dilakukan di Dusun Kabun Barudisambut baik oleh perangkat dusun dan anggota kelompok PKK. Berdasarkan rangkaian kegiatan yang dilakukan peserta kelompok PKK telah mampu membuat berbagai jenis tusuk sulam dan mampu membuat hiasan dengan teknik sulam pada benda-benda kriya seperti sendal, dan dompet. Dengan pengetahuan yang diperoleh kelompok PKK dapat lebih kreatif dan inovatif dalam menghasilkan motif baru dan dapat secara mandiri berupaya menemukan identitas mereka

Program pelatihan ini diharapkan dapat dilaksanakan secara berkesinambungan. Hal ini tentunya atas kesadaran masyarakat dan motivasi dari penggerak PKK dan pemerintahan setempat. Untuk jangka panjang diharapkan kelompok PKK dapat mengenalkan dan 
mengembangkan ilmu mereka kepada masyarakat umum yang ada di dusun Kabun Baru dan Kecamatan Lubuk Alung, sehingga dapat mengembangkan ketrampilan menjadi sentral kerajinan rumah tangga di Lubuk Alung.

Tim pengabdian mengucapkan terimakasih sebesar-besarnya kepada Lembaga Institut Seni Indonesia, Lembaga pengabdian pada masyarakat (LPPMPP) ISI, dan kelompok PKK Dusun Kabun Baru Balah Hilir Kecamatan Lubuk Alung yang telah memberikan dukungan sehingga kegiatan pengabdian masyarakat Dana DIPA 2018 dengan Surat Penugasan Pelaksanaan Pengabdian kepada Masyarakat Nomor: 099/ IT7/ KPT/ 2018, dapat terlaksana,

\section{DAFTAR PUSTAKA}

Aswar, Sativa Sutan, 1999, Antakesuma Suji Dalam Adat Minangkabau, Djambatan, Jakarta.

Buku Rakernas PKK, 2015, https://tppkk-pusat.org, diunduh tanggal 29 Agustus 2018 jam 10.00 WIB.

Fitri, 2013, Kerajinan Sulaman di Nagari Koto Baru Simalanggang Kecamatan Payakumbuh Kabupaten Lima Puluh Kota, E-Journal Home Economic and Tourism, Vol. 4 (No. 3).

Suherno, Hery, 2004, Desain Motif, Pustaka Pembangunan Swadaya Nusantara, Jakarta.

Soemantri, V. M. Bambang, 2005, Tusuk Sulam Dasar, IKPI, Jakarta.

Yulimarni \& Nofi Rahmanita, 2017, Kain Perca sebagai Media Kreasi PKK di Nagari Sungai Abang Kecamatan Lubuk Alung, Batoboh: Jurnal Pengabdian pada Masyarakat, Vol. 3 (No.2), Hal. 121.

Zulkarnaen, Yossi, 2006,Sulam Benang untuk Pemula,Puspa Swara, Jakarta. , 2010,Sulaman Kombinasi Aneka Motif, Kriya Pustaka, Jakarta. 